\title{
EDITOR'S FOREWORD
}

Dr. Heinrich Zimmer's posthumous chapters for a projected volume on the philosophies of India were found in various stages of completion. Those on the meeting of the Orient and Occident, the Indian philosophy of politics, Jainism, Sānkhya and Yoga, Vedānta, and Buddhahood had served as notes for a course of lectures delivered at Columbia University in the spring of 1942 , while that on the Indian philosophy of duty had opened the course for the spring of 1943 . But since hardly five weeks of the latter term had been completed when Dr. Zimmer was stricken with his final illness, his materials treating of the other phases of Indian thought remained in the uneven condition of mere jottings and preliminary drafts. All were found in a single, orderly file, however, so that the problem of arranging them was not difficult. Lacunae could be filled from other bundles of manuscript, as well as from recollected conversations. The editing of most of the chapters, therefore, went rather smoothly. But toward the end the condition of the notes became so rough and spotty that the merely indicated frame had to be filled in with data drawn from other sources.

I have quoted only from authors suggested either in Dr. Zimmer's outline or in his class assignments, and have named them all clearly in my footnotes. In the chapter on The Great Buddhist Kings, which is the first in which this problem arose, my chief authorities were The Cambridge History of India, Vol. I; E. B. Havell, The History of Aryan Rule in India from 
the Earliest Times to the Death of Akbar; Ananda K. Coomaraswamy, Buddhism and the Gospel of Buddhism; T. W. Rhys Davids, Buddhism, Its History and Literature; S. Radhakrishnan, Indian Philosophy; Vincent A. Smith, Asoka, The Buddhist Emperor of India; and L. de la Vallée Poussin's article on the Buddhist Councils and Synods in Hastings' Encyclopaedia of Religion and Ethics. The notes for the chapter on Hinayana and Mahāyāna Buddhism were quite full, though not yet amplified into a continuously inspired exposition. I simply arranged them and opened the brief sentences into running prose, bridging two short gaps with quotations from S. Radhakrishnan, as indicated in my footnotes. I was particularly distressed, however, to find that the materials for the chapters on The Way of the Bodhisattva, The Great Delight, and Tantra were very sparse and only partially developed; for these were themes to which Dr. Zimmer had been devoting much attention during the latter years of his life, and on which he had been extraordinarily eloquent in conversation. I could find only a few additional bits of paper scattered through the volumes of his library, and these together with what I remembered of our talks had to suffice to eke out the notes. The reader should bear in mind that in these last pages Dr. Zimmer's position may not be quite correctly represented. I have been able to give only a few brief but precious fragments, framed in a setting largely quoted from Swami Nikhilananda's translation of The Gospel of Sri $R \bar{a}-$ makrishna and Sir John Woodroffe's Shakti and Shäkta.

Obviously, the history of Indian philosophy here before us is far from what it would have been had Dr. Zimmer lived. The broad sweep of the basic structural ideas carries to completion of itself, however, even where the outlines are no more than indicated, an extraordinary vision not only of the Indian but also of the Western philosophical development. Hence, though the work as it stands is visibly but a fragment (a large and awesome fragment, comparable, one might say, to the unfinished stupa 


\section{EDITOR'S FOREWORD}

at Borobudur) formally it makes a cogent and prodigious statement. The whole is conceived primarily as an introduction to the subject, each chapter leading to the next, and not as a handbook; but I have supplied cross-references and Mr. William McGuire has prepared a copious index, to serve the reader wishing to study any separate topic. Guidance to further reading will be found in the bibliography and in the titles cited in the footnotes.

My profound thanks go to Swami Nikhilananda for kind permission to quote extensively from his translation of The Gospel of Srī Rāmakrishna, to Doña Luisa Coomaraswamy for Plates I, II, III, V, IX, X, and XII, Dr. Stella Kramrisch for Plates VIII and XI, and Dr. Marguerite Block for Plate VIa. The Metropolitan Museum of Art kindly supplied Plates IV and VIb, the Morgan Library Plate VIc, and the Asia Institute Plate VII. I owe much, moreover, to Mrs. Wallace Ferguson for assistance in the final editing of the manuscript, to Miss Elizabeth Sherbon for three years of tireless and painstaking typing, to Mr. William McGuire for his meticulous editing of the proofs and for his above-mentioned index, and to my wife for all her hours of listening and for numberless suggestions.

New York City

J. C.

March 20, 195 I 
